TAPROBANICA, ISSN 1800-427X. January, 2015. Vol. 07, No. 01: pp. 47-48, pl. 18-19.

(C) Research Center for Climate Change, University of Indonesia, Depok, Indonesia

\& Taprobanica Private Limited, Homagama, Sri Lanka

www.taprobanica.org

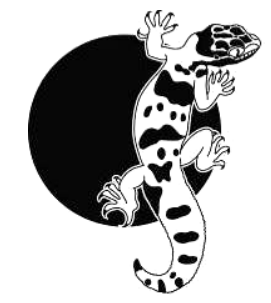

\section{Range extension of Pethia nigripinna (Cyprinidae) to Karnataka, India}

The black-finned barb, Puntius nigripinnis Knight et al., 2012 currently designated to the genus Pethia Pethiyagoda et al., 2012 is a little known barb described from the east flowing Cauvery River basin (Knight et al., 2012). The present knowledge on the range of Pethia nigripinna (Knight et al., 2012) is based only from its original description, as there have been no subsequent records of this species from the Western Ghats. Until now, $P$. nigripinna is known to occur only in Kalindhi stream, Kabini River in Wayanad, Kerala and Kakkan halla, Moyar River, Tamil Nadu.

During a recent survey of Southern Karnataka, specimens of Pethia nigripinna were collected from three additional localities. Two of present collection localities fall within the same east flowing Cauvery River basin, while the other locality falls on the west flowing Barapole River, which flows thorough Valapattinam, Kerala and eventually drains into the Arabian Sea. The two new locations of $P$. nigripinna in the Cauvery River basin are streams in Kalur $\left(12^{\circ} 28^{\prime} 17^{\prime \prime} \mathrm{N}, \quad 75^{\circ} 44^{\prime} 25^{\prime \prime} \mathrm{E}\right)$ and Hattihole $\left(12^{\circ} 29^{\prime} 11^{\prime N}, 75^{\circ} 47^{\prime} 47^{\prime \prime E}\right)$, Madhikeri, Kodagu district, Karnataka. Specimens of P. nigripinna were also collected from the Barapole River $\left(12^{\circ} 01^{\prime} 50^{\prime \prime} \mathrm{N}, 75^{\circ} 55^{\prime} 42^{\prime \prime E}\right)$, Coorg, Karnataka, thus extending the range of $P$. nigripinna from the east flowing Cauvery River basin to the west flowing Barapole River (Fig. 1). A total of 4 specimens of $P$. nigripinna were collected from these three locations. The specimens were identified as $P$. nigripinna based on the absence of barbels and having the last unbranched dorsal ray serrated (see Knight et al., 2012). The specimens had an incomplete lateral line with 20-21 scales in lateral series. The dorsal, anal, pelvic and pectoral fins were black in adult males and the dorsal and anal fins were pale red in females. The body pattern consisted of a black humeral spot on the 3rd or 4th lateral-line scale and a second larger spot on the 18th and 19th scale, which formed a ring around the caudal peduncle having only two scales between the second spot and the hypural notch (Fig. 2). The specimens of $P$. nigripinna were collected from fast flowing streams as well as riffles with overhanging terrestrial vegetation which provide shady retreats for the species. Pethia nigripinna were found moving in small shoals of 2 to 3 individuals and were quick to hide when disturbed. In the Cauvery River headwaters, $P$. nigripinna was found to co-exist with loaches (Schistura sp. and Mesonemacheilus sp.), Baril (Barilius gatensis), Wayanad mahseer (Neolissochilus wynaadensis) and a few stone suckers (Garra sp.).

Wherever collected, $P$. nigripinna was not abundant. Only a few individual were seen and a fewer were collected. Currently the status of the species and the possible threats are unknown. It is possible that habitat destruction as well as pollution caused by the discharge of domestic sewage and other chemical pollutants like pesticides and fertilizers carried by surface water runoffs could impact the species. It is true that the present knowledge on the diversity of freshwater fishes of Western Ghats is far from complete (Ali et al., 2013a) and Wallacean shortfall, which concerns the deficiency of knowledge of species distribution at different geographical scales is to be blamed for many premature claims of local extinction of fish species (Knight, 2010). In recent times, large fish species are getting the required attention when it comes to bridging the knowledge gap on species distribution (Ali et al., 2013a, b; Knight et al., 2013a,b,c). However, it is the population and distribution of diminutive species such as $P$. nigripinna that need to be monitored before habitat destruction and other anthropogenic factors drive them to the brink of extinction (Knight 2014). 
Comparative materials: Pethia nigripinna: ZSI/SRC F. 6628, 1 ex. (Holotype) 45.0mm SL, Kalindhi stream of river Kabini, Wyanad, Kerala; Paratypes: ZSI/SRC F. 6629, 3 exs., $33.0-38.0 \mathrm{~mm}$ SL, Kalindhi stream of river Kabini, Wyanad, Kerala; ZSI/SRC F. 6578, 2 exs., 34.0-39.0 mm SL, Kakkan halla, Moyar River, Tamil Nadu.

\section{Literature cited}

Ali, A., S. Philip, N. Dahanukar, C.R. Renjithkumar, A. Bijukumar, and R. Raghavan, 2013a. Distribution, threats and conservation status of Hypselobarbus thomassi (Day, 1874), a poorly known cyprinid fish of the Western Ghats freshwater ecoregion. Journal of Threatened Taxa, 5: 5202-5213.

Ali, A., S. Philip, and R. Raghavan, 2013b. Back from obscurity: notes on the current distribution, threats and conservation status of a poorly known cyprinid, Hypselobarbus lithopidos (Day, 1874) from the Western Ghats of India. Journal of Threatened Taxa, 5: 4743-4751.

Knight, J.D.M., 2010. Addressing the wallacean shortfall: an updated Checklist of Icthyofauna of Chembarampakkam tank. Taprobanica, 2: 25-29.

Knight, J.D.M., K. Rema Devi, T.J. Indra, and M. Arunachalam, 2012. A new species of barb Puntius nigripinnis (Teleostei: Cyprinidae) from southern Western Ghats, India. Journal of Threatened Taxa, 4: 2409-2416.

Knight, J.D.M., A. Rai, and R.K.P. D'souza, 2013a. Re-description of Hypselobarbus lithopidos (Teleostei: Cyprinidae), based on its rediscovery from the Western Ghats, India, with notes on H.thomassi. Journal of Threatened Taxa, 5: 47344742.

Knight, J.D.M., A. Rai, and R.K.P. D'souza, 2013b. Rediscovery of Hypselobarbus pulchellus, an endemic and threatened barb (Teleostei: Cyprinidae) of the Western Ghats, with notes on $H$. dobsoni and H. jerdoni. Journal of Threatened Taxa, 5: 5194-5201.

Knight, J.D.M., A. Rai, and R.K.P. D'souza. 2013c. On the identities of Barbus mussullah Sykes and Cyprinus curmuca Hamilton with notes on the status of Gobio canarensis Jerdon (Teleostei: Cyprinidae). Zootaxa, 3750: 201-215.
Knight, J.D.M., 2014. Oreichthys andrewi (Teleostei: Cyprinidae) a new species from Assam, northeastern India. Journal of Threatened Taxa, 6: 5357-5361.

Pethiyagoda, R., M. Meegaskumbura, and K. Maduwage, 2012. A synopsis of the South Asian fishes referred to Puntius (Pisces: Cyprinidae). Ichthyological Exploration of Freshwaters, 23: 69-95.

Submitted: 16 Apr. 2014, Accepted: 02 Jan. 2015 Section Editor: Sujan M. Henkanaththegedara

J. D. M. Knight ${ }^{1}$, A. Rai ${ }^{2}$, R. K.P. D’souza

\& B. Vijaykrishnan

${ }^{1}$ Flat L, Sri Balaji Apartments, 7th Main Road, Dhandeeswaram, Velachery, Chennai, Tamil Nadu 600042, India E-mail: jdmarcusknight@yahoo.co.in

${ }^{2}$ Department of Fisheries Microbiology, College of Fisheries, Yekkur, Mangalore, Karnataka 575002, India

\footnotetext{
${ }^{3}$ Department of Applied Zoology, Mangalore University, Mangalagangothri, Manglore, Karnataka 574199, India

${ }^{4}$ 15/21, Sambasivam Street, T.Nagar, Chennai 600017, Tamil Nadu, India
} 


\section{PLATE 18}



Figure 1: Map showing collection localities of Pethia nigripinna from the Western Ghats: A, Kalur, Karnataka;

B, Hattihole, Karnataka; C, Barapole, Karnataka; D, Kalindhi stream, Kabini, Kerala; E, Kakkan halla, Moyar, Tamil Nadu. 


\section{PLATE 19}

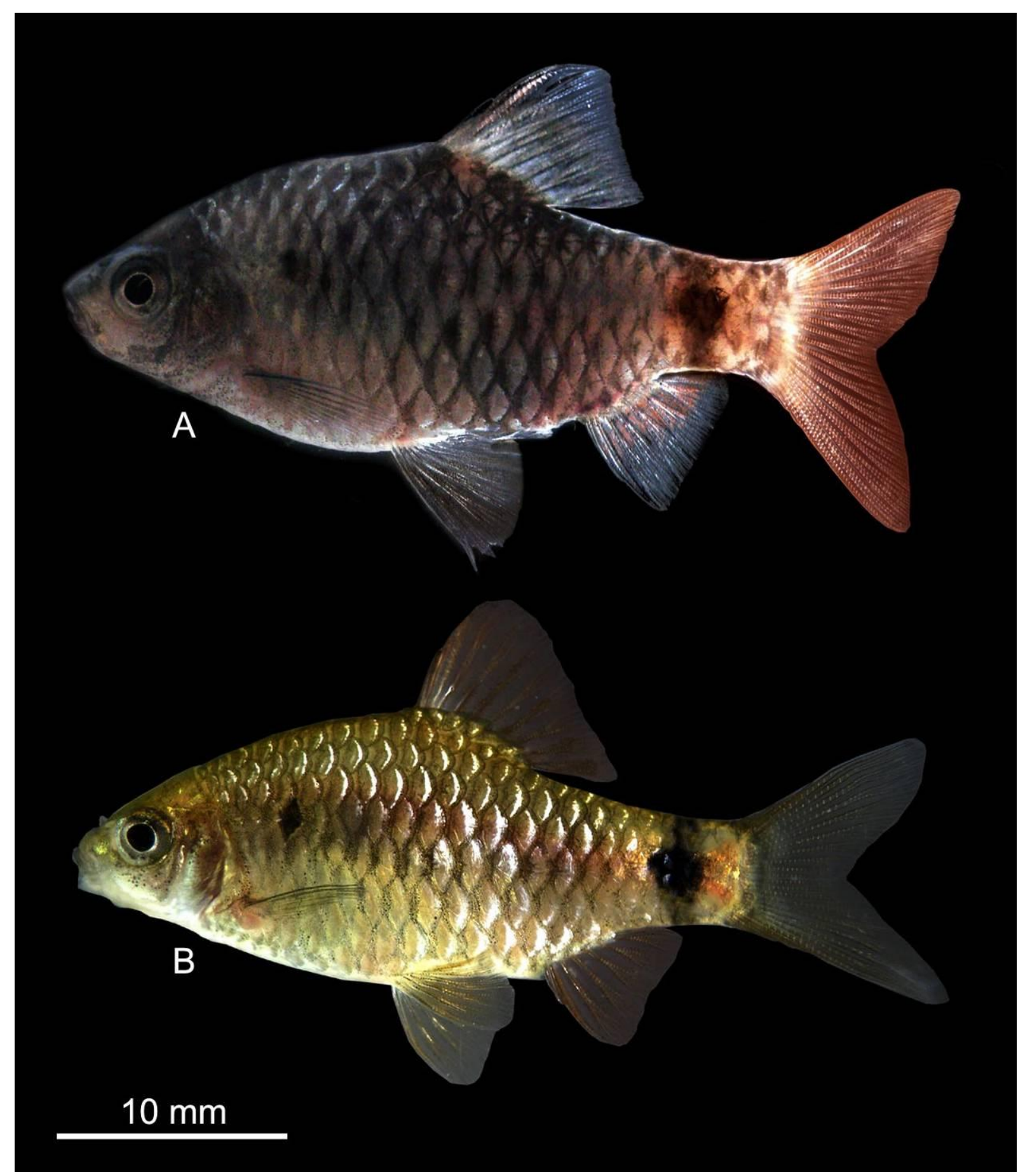

Figure 2: Pethia nigripinna A, Male from Kalindhi stream, Kabini River, Wayanad, Kerala; B, Female from Barapole River, Coorg, Karnataka. 